\title{
Cyclization Reactions of Acylium and Thioacylium Ions with Isocyanates and Isothiocyanates: Gas Phase Synthesis of 3,4-Dihydro-2,4-Dioxo-2H-1,3,5- Oxadiazinium Ions
}

\author{
Eduardo C. Meurer, Regina Sparrapan, Daniela M. Tomazela, \\ and Marcos N. Eberlin \\ Institute of Chemistry, State University of Campinas, UNICAMP, Campinas, Brazil \\ Rodinei Augusti \\ Chemistry Department, Federal University of Minas Gerais, Belo Horizonte, Brazil
}

Gas-phase reactions of several acylium and thioacylium ions, that is $\mathrm{H}_{2} \mathrm{C}=\mathrm{N}-\mathrm{C}^{+}=\mathrm{O}, \mathrm{H}_{2} \mathrm{C}=\mathrm{N}$ $\mathrm{C}^{+}=\mathrm{S}, \mathrm{O}=\mathrm{C}=\mathrm{N}-\mathrm{C}^{+}=\mathrm{O}, \mathrm{S}=\mathrm{C}=\mathrm{N}-\mathrm{C}^{+}=\mathrm{O}, \mathrm{H}_{3} \mathrm{C}-\mathrm{C}^{+}=\mathrm{O}$, and $\left(\mathrm{CH}_{3}\right)_{2} \mathrm{~N}-\mathrm{C}^{+}=\mathrm{O}$, with both a model isocyanate and isothiocyanate, that is, $\mathrm{C}_{2} \mathrm{H}_{5}-\mathrm{N}=\mathrm{C}=\mathrm{O}$ and $\mathrm{C}_{2} \mathrm{H}_{5}-\mathrm{N}=\mathrm{C}=\mathrm{S}$, were investigated using tandem-in-space pentaquadrupole mass spectrometry. In these reactions, the formation of mono- and double-addition products is observed concurrently with proton transfer products. The double-addition products are far more favored in reactions with ethyl isocyanate, whereas the reactions with ethyl isothiocyanate form, preferentially, either the mono-addition product or proton transfer products, or both. Retro-addition dominates the low-energy collision-induced dissociation of the mono- and double-addition products with reformation of the corresponding reactant ions. Ab initio calculations at Becke3LYP//6-311 + $\mathrm{G}(\mathrm{d}, \mathrm{p})$ level indicate that cyclization is favored for the double-addition products and that products equivalent to those synthesized in solution, that is, of 3,4-dihydro-2,4-dioxo-2H-1,3,5oxadiazinium ions and sulfur analogs, are formed. (J Am Soc Mass Spectrom 2005, 16, 1602-1607) (C) 2005 American Society for Mass Spectrometry

$\mathrm{T}$ landem mass spectrometry [1-3] $\left(\mathrm{MS}^{\mathrm{n}}\right)$ provides not only a means to perform gas-phase ion/ molecule reactions with isolated and massselected ions under well-defined conditions but also the on-line structural analysis of each product ion. $\mathrm{MS}^{\mathrm{n}}$ constitutes, therefore, a refined tool to perform elegant studies of the inherent properties, reactivity, and structures of gaseous ions with molecules of many classes [1-9]. MS ${ }^{n}$ experiments performed in this solvent- and counterion-free environment has been also of fundamental importance to understand and elucidate reaction mechanisms and to draw parallels to condensed-phase reactivity [4-19]. Tandem mass spectrometers also provide minute but very efficient synthetic laboratories [20-22] with some attractive possibilities for product collection such as ion soft-landing [23].

We have observed that acylium ions, a common class

Published online August 8, 2005

Address reprint requests to Dr. R. Augusti, Chemistry Department, Federal University of Minas Gerais, Belo Horizonte 31270-901 MG, Brazil. E-mail: augusti@ufmg.br of gaseous ions, react promptly and diversely with many classes of compounds including acetals [24, 25], epoxydes, [26] $\alpha$-hydroxi-ketones, [27], dienes, [28] and $\alpha, \beta$-unsaturated ketones [29]. Recently, we reported that acylium ions also react readily with nitriles (M) via double nitrile addition followed by cyclization (Scheme 1) to form, via the intermediacy of mono-addition products $\left(\mathrm{MAc}^{+}\right)$, the aromatic 1,3,5-oxadiazinium ions $\left(\mathrm{M}_{2} \mathrm{Ac}^{+}\right)$[30].

Acylium ions are also important species in solution playing a fundamental role in the well-known and industrially relevant Friedel-Crafts acylation reaction [31]. They are also useful intermediates in the condensed-phase synthesis of many heterocycles via reactions with cyanamides, carbodiimides, alkenes, alkynes, and nitriles [32]. Solvated acylium ions were also found to react with alkyl isocyanates to yield unique double-addition cyclic products, namely, 3,4dihydro-2,4-dioxo-2H-1,3,5-oxadiazinium salts in moderate yields [33].

Therefore, owing to the rich and useful reactivity exhibited by acylium ions in both the condensed and gas phases, and to our continuous interest in exploring 


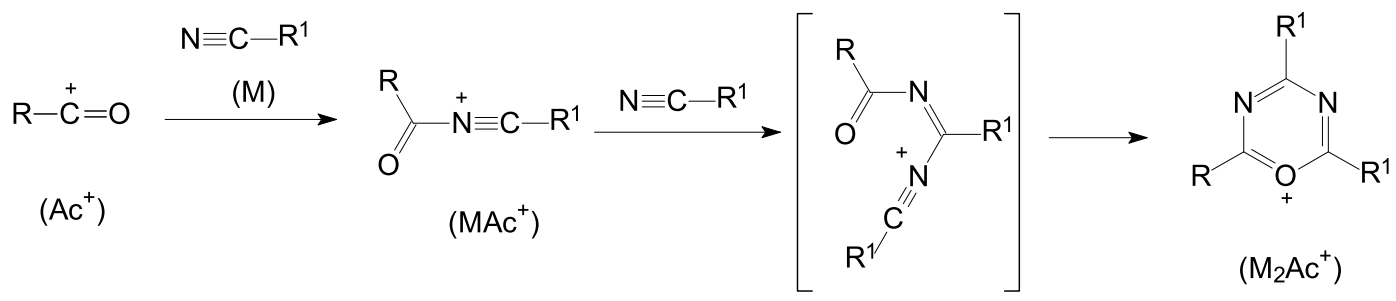

Scheme 1

ion reactivities and the synthetic and analytical applications of their gas-phase reactions, herein we investigated, using tandem-in-space pentaquadrupole mass spectrometry, [7] the intrinsic reactivity of gaseous, solvent-, and counter-ion free acylium and thioacylium ions toward isocyanates and isothiocyanates.

\section{Experimental}

Chemical reagents were purchased from Aldrich (Milwaukee, WI) and used without further purification. Double-stage $\left(\mathrm{MS}^{2}\right)$ and triple-stage $\left(\mathrm{MS}^{3}\right)$ mass spectrometry experiments were performed with an Extrel (Pitsburgh, PA) pentaquadrupole $\left(\mathrm{Q}_{1} \mathrm{q}_{2} \mathrm{Q}_{3} \mathrm{q}_{4} \mathrm{Q}_{5}\right)$ mass spectrometer [34]. The following precursors were used to generate the reactant ions in the ion source via $70 \mathrm{eV}$ electron ionization: $\mathrm{H}_{2} \mathrm{C}=\mathrm{N}-\mathrm{C}^{+}=\mathrm{O}$ (ethyl isocyanate), $\mathrm{H}_{2} \mathrm{C}=\mathrm{N}-\mathrm{C}^{+}=\mathrm{S}$ (ethyl isothiocyanate), $\mathrm{O}=\mathrm{C}=\mathrm{N}-\mathrm{C}^{+}=\mathrm{O}$ (ethoxycarbonyl isocyanate), $\mathrm{S}=\mathrm{C}=\mathrm{N}-\mathrm{C}^{+}=\mathrm{O}$ (ethoxycarbonyl isothiocyanate), $\mathrm{H}_{3} \mathrm{C}-\mathrm{C}^{+}=\mathrm{O}$ (methyl phenyl ketone), $\left(\mathrm{CH}_{3}\right)_{2} \mathrm{~N}-\mathrm{C}^{+}=\mathrm{O}$ (tetramethyl urea). For the $\mathrm{MS}^{2}$ experiments, the ion of interest was mass-selected in $\mathrm{Q}_{1}$ and reacted in $\mathrm{q}_{2}$ with the neutral isocyanate or isothiocyanate. Ion translational energies were set to $\sim 1$ $\mathrm{eV}$, as calibrated by the $\mathrm{m} / \mathrm{z} 39: 41$ ratio in neutral ethylene/ionized ethylene reactions [35]. To record the

Table 1. Summary of the product ion mass spectra for reactions of the acylium and thioacylium ions 1-6 $\left(\mathrm{Ac}^{+}\right)$with both ethyl isocyanate 7 and ethyl isothiocyanate 8

\begin{tabular}{|c|c|c|c|c|}
\hline M & $\mathrm{Ac}^{+}$ & $\begin{array}{c}\mathrm{MAc}^{+} \mathrm{m} / \mathrm{z} \\
\text { (rel. intensity) }\end{array}$ & $\begin{array}{c}\mathrm{M}_{2} \mathrm{Ac}^{+} \mathrm{m} / \mathrm{z} \\
\text { (rel. intensity) }\end{array}$ & $\begin{array}{c}\left(\mathrm{M}_{2} \mathrm{H}^{+}\right),\left(\mathrm{MH}^{+}\right) \\
m / z \text { (rel. } \\
\text { intensity) }\end{array}$ \\
\hline \multirow[t]{6}{*}{7} & 1 & $127(7)$ & $198(100)$ & $143(20), 72(13)$ \\
\hline & 2 & a & $214(0)$ & a \\
\hline & 3 & $141(13)$ & $212(100)$ & $143(7), 72(42)$ \\
\hline & 4 & 157 (17) & $228(100)$ & $143(2), 72(5)$ \\
\hline & 5 & $114(52)$ & $185(44)$ & $143(100), 72(2)$ \\
\hline & 6 & a & $214(8)$ & $a$ \\
\hline \multirow[t]{6}{*}{8} & 1 & $143(0)$ & $230(0)$ & $175(0), 88(100)$ \\
\hline & 2 & $159(100)$ & $246(5)$ & $175(65), 88(14)$ \\
\hline & 3 & $157(18)$ & $244(0)$ & $175(32), 88(100)$ \\
\hline & 4 & $173(0)$ & $260(0)$ & $175(0), 88(100)$ \\
\hline & 5 & $130(0)$ & $217(0)$ & $175(0), 88(100)$ \\
\hline & 6 & $159(100)$ & $246(2)$ & $175(90), 88(10)$ \\
\hline
\end{tabular}

aln reactions of $\mathbf{2}$ and $\mathbf{6}$ with ethyl isocyanate 7, the following ions are isobaric (the same $\mathrm{m} / \mathrm{z}$ ratio) and therefore could not be distinguished: (i) the mono-addition product $\mathrm{MAc}^{+}$and the proton-bound dimer $\mathrm{M}_{2} \mathrm{H}^{+}$ $(\mathrm{m} / \mathrm{z} 143)$; and (ii) the reactant ion (2 or $\mathbf{6})$ and the protonated neutral $\mathrm{MH}^{+}(\mathrm{m} / \mathrm{z}$ 72). product ion mass spectra, $\mathrm{Q}_{5}$ was scanned while operating $\mathrm{Q}_{3}$ in the broadband rf-only mode. Multiple collision conditions, which caused typical beam attenuation of 50 to $70 \%$, were used in $\mathrm{q}_{2}$ to increase reaction yields and to promote collisional quenching of both the reactant and product ions [7]. For the $\mathrm{MS}^{3}$ experiments, [36] the products formed in $\mathrm{q}_{2}$ were mass-selected in $\mathrm{Q}_{3}$ and further dissociated by $15 \mathrm{eV}$ collision energy with argon in $\mathrm{q}_{4}$ while scanning $\mathrm{Q}_{5}$. The $15 \mathrm{eV}$ collision energy was measured by the voltage difference between the ion source and the collision quadrupoles. The pressures in each mass spectrometer sector were typically: 2 $\times 10^{-6}$ (ion source), $8-10^{-6}\left(\mathrm{q}_{2}\right)$, and $8 \times 10^{-5}\left(\mathrm{q}_{4}\right)$ torr.

Optimized geometries and energies of idealized conformations were obtained by theoretical calculations without symmetry constraints using Becke3LYP [37-39] DFT/HF hybrid functionals and 6-311 + G(d,p) basis sets as implemented in Gaussian 98 [40]. These structures are available from the authors upon request.

\section{Results and Discussion}

Table 1 summarizes the product ion mass spectra collected for the reactions of the acylium and thioacylium ions 1-6 $\left(\mathrm{Ac}^{+}\right)$(Scheme 2) with both ethyl isocyanate 7 and ethyl isothiocyanate 8 (M) (Scheme 3) selected as model compounds. Additionally, Figure 1 displays, as an illustrative example, the product ion mass spectrum for the reaction of acylium ion $\mathbf{1}$ with isocyanate 7 .

In general and under the multiple-collision conditions employed in the rf-only quadrupole collision cell, two major and competing reactions occur (Scheme 4): (i) proton transfer to the neutral $(\mathrm{M})$ either from the

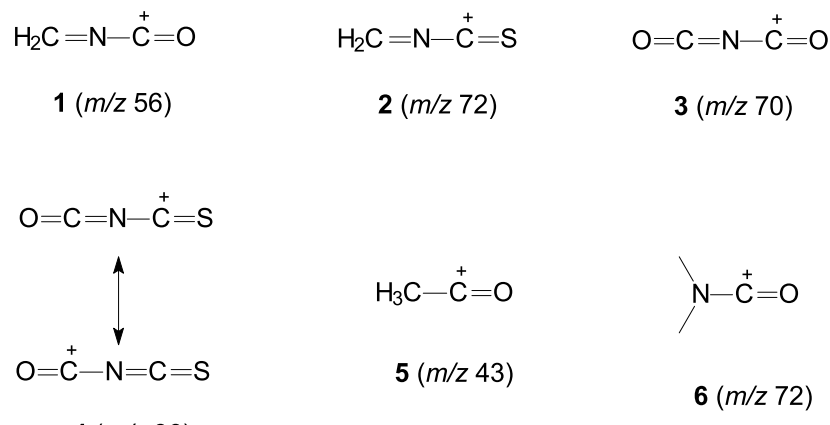

$4(m / z 86)$

Scheme 2 


$$
\begin{gathered}
\mathrm{C}_{2} \mathrm{H}_{5}-\mathrm{N}=\mathrm{C}=\mathrm{O} \\
7(71 \mathrm{Da})
\end{gathered}
$$

$$
\begin{gathered}
\mathrm{C}_{2} \mathrm{H}_{5}-\mathrm{N}=\mathrm{C}=\mathrm{S} \\
\mathbf{8}(87 \mathrm{Da})
\end{gathered}
$$

Scheme 3

reactant ion $\mathrm{Ac}^{+}$or its products; and (ii) mono- $\left(\mathrm{MAc}^{+}\right)$ and double-addition $\left(\mathrm{M}_{2} \mathrm{Ac}^{+}\right)$products. For instance, in Figure 1 the mono- and double-addition adducts are those of $m / z 127$ and 198, respectively, whereas the products of $m / z 72\left(\mathrm{MH}^{+}\right)$and $143\left(\mathrm{M}_{2} \mathrm{H}^{+}\right)$arise by proton transfer. Although the structure of the doubleaddition product $\left(\mathrm{M}_{2} \mathrm{Ac}^{+}\right)$may be either acyclic or cyclic, ab initio calculations indicate that the cyclic structures presented in Scheme 4 are far more stable (see below). Note that these cyclic structures are equivalent to those synthesized in solution [33] and analogous to those observed for the double nitrile addition products of acylium ions (Scheme 1) [30].

The data of Table 1 reveal that ethyl isocyanate 7 reacts with 1,3 , and 4 to yield mainly the doubleaddition product $\mathrm{M}_{2} \mathrm{Ac}^{+}$. The acetyl cation 5 also reacts with 7 to form $\mathrm{M}_{2} \mathrm{Ac}^{+}$to some extent, but this ion is the only one that provides greater yields of both the proton transfer products $\mathrm{MH}^{+}$and $\mathrm{M}_{2} \mathrm{H}^{+}$and the monoadduct $\mathrm{MAc}^{+}$. In reactions of ethyl isocyanate 7 with 2 and 6, the product ions $\mathrm{MAc}^{+}$and $\mathrm{M}_{2} \mathrm{H}^{+}(m / z$ 143), as well as the reactant cations ( 2 or 6$)$ and $\mathrm{MH}^{+}(\mathrm{m} / \mathrm{z} 72)$, are isobaric and thus could not be distinguished. Furthermore, none (2) or little (6) of the double-addition product $\mathrm{M}_{2} \mathrm{Ac}^{+}(\mathrm{m} / \mathrm{z} 214)$ is formed in these reactions. With the sulfur analog 8, ethyl isothiocyanate, none (1, 3,4 , and 5) or little (2 and 6) of $\mathrm{M}_{2} \mathrm{Ac}^{+}$is formed; 2 and 6 yield mainly $\mathrm{MAc}^{+}$whereas 1, 3, and 5 form predominantly $\mathrm{MH}^{+}$and $\mathrm{M}_{2} \mathrm{H}^{+}$.

The contrasting product distributions verified in these reactions are likely influenced by the proton affinity (PA) of the neutral compound $\mathrm{M}$ as well as the gas-phase acidity of the reactant ion $\mathrm{Ac}^{+}$. For instance, proton-transfer products are preferentially formed with the model ethyl isothiocyanate 8 likely because of its greater proton affinity than that of ethyl isocyanate 7 . This assumption is supported by reference proton affinity data [41] showing that PA of methyl isothiocyanate $\left(799.2 \mathrm{~kJ} \mathrm{~mol}^{-1}\right)$, the lower homologue of $\mathbf{8}$, is considerably greater than that of methyl isocyanate

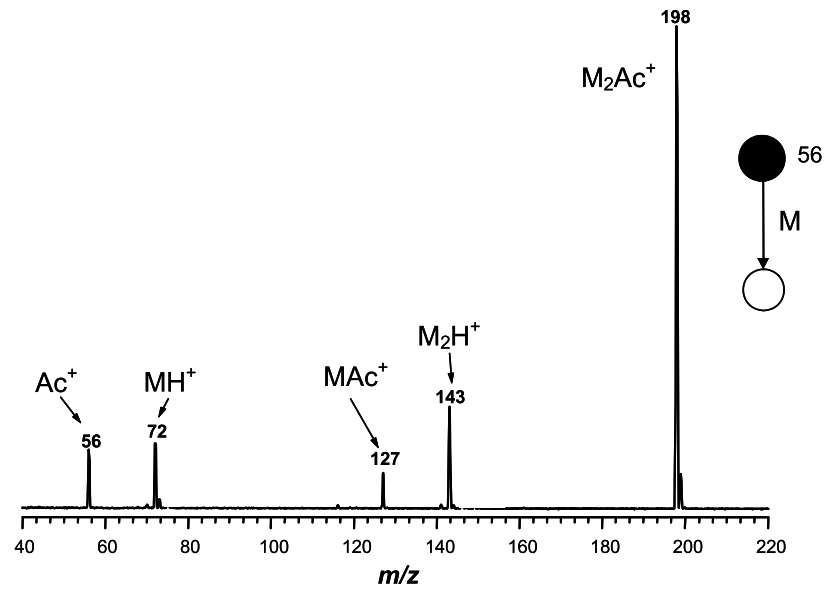

Figure 1. Product-ion mass spectrum for the reaction of the acylium ion $\mathbf{1}\left(\mathrm{Ac}^{+}\right)$with ethyl isocyanate $\mathbf{7}(\mathrm{M})$.

(764.4 kJ.mol $\left.{ }^{-1}\right)$, the lower homologue of 7. For reactant ions, the acetyl cation 5 (protonated ketene) shows the greatest tendency to react by proton transfer owing to its high gas-phase acidity, the highest among the ions investigated [7].

\section{CID Experiments}

CID experiments were performed in trying to obtain structural information for products $\mathrm{MAc}^{+}$and $\mathrm{M}_{2} \mathrm{Ac}^{+}$. As an example, Figure 2 shows the sequential product ion mass spectra $\left(\mathrm{MS}^{3}\right)$ of the mono- and double-addition products from the reaction of $\mathbf{1}$ with 7. Both $\mathrm{M}_{2} \mathrm{Ac}^{+}$of $\mathrm{m} / \mathrm{z} 198$ and $\mathrm{MAc}^{+}$of $\mathrm{m} / \mathrm{z} 127$ dissociate by retro-addition, that is, $\mathrm{M}_{2} \mathrm{Ac}^{+}$dissociates to $\mathrm{MAc}^{+}$whereas $\mathrm{MAc}^{+}$dissociates to $\mathrm{Ac}^{+}$.

The $[\mathrm{O}=\mathrm{C}=\mathrm{N}-\mathrm{C}=\mathrm{S}]^{+}$Ion

The singly charged acylium-thioacylium ion 4 , that is $[\mathrm{O}=\mathrm{C}=\mathrm{N}=\mathrm{C}=\mathrm{S}]^{+}$, represents a special and interesting case since its initial addition to neutrals 7 or 8 may occur either via its $C=O$ or $C=S$ charge sites (Scheme 5), or via both sites, with the formation of either $10 a$ or $10 b$, and either acyclic (11a or $\mathbf{1 1 b}$ ) or cyclic (12a or 12b) double-addition products. However, as these adducts dissociate only by retro-addition ( $\mathrm{MS}^{3}$ data not shown),
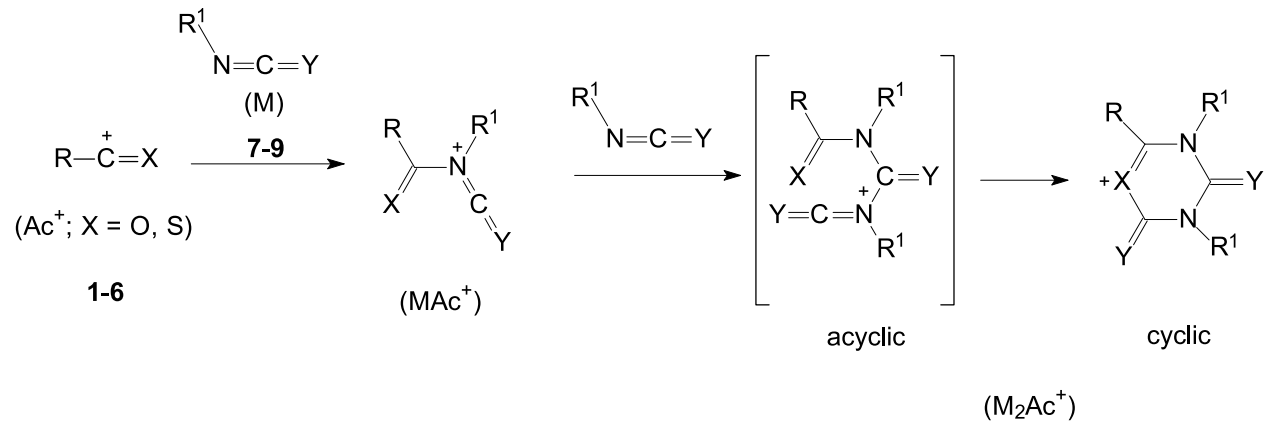

Scheme 4 


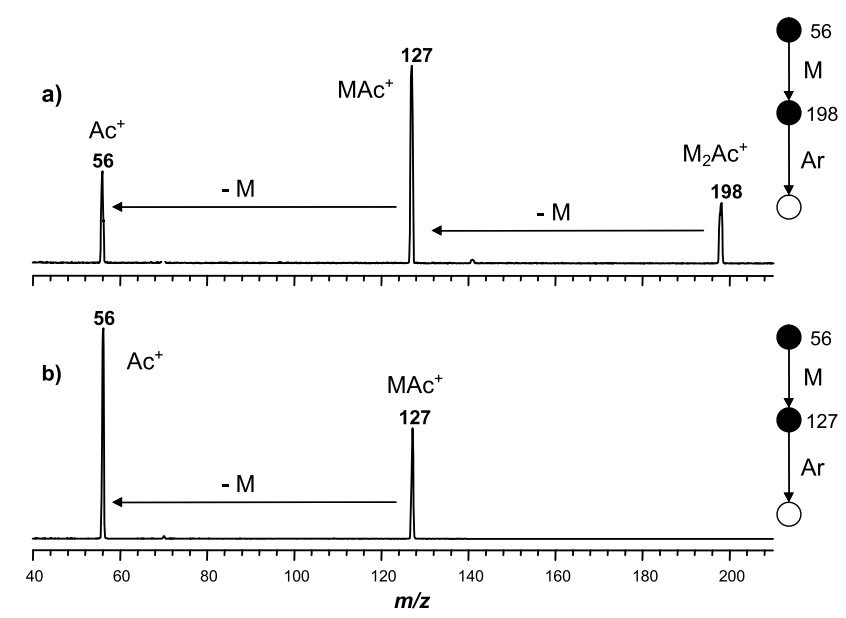

Figure 2. Sequential product ion mass spectra for (a) $\mathrm{M}_{2} \mathrm{Ac}^{+}$and (b) $\mathrm{MAc}^{+}$formed in the reaction of ethyl isocyanate 7 (M) with acylium ion 1.

no information about which isomeric product is preferentially formed is provided; hence we had to rely on theoretical predictions (see below).

\section{Ab Initio Calculations: Reaction Enthalpies}

$\mathrm{Ab}$ initio calculations were performed to compare the thermodynamic stabilities of the addition products. Figure 3 shows, as an example, the energy diagram calculated for the reaction of the singly charged acylium-thioacylium ion $[\mathrm{O}=\mathrm{C}=\mathrm{N}=\mathrm{C}=\mathrm{S}]^{+}$(4) with 7. Both mono-addition products $10 \mathrm{a}$ and $10 \mathrm{~b}$ (Scheme 5) are 70.3 and $100.0 \mathrm{~kJ} \mathrm{~mol}^{-1}$ more stable in respect to the initial reagents. Therefore, the initial addition of 7 to the $\mathrm{C}=\mathrm{S}$ charge site of 4 is $29.7 \mathrm{~kJ} \mathrm{~mol}^{-1}$ more exothermic than $\mathrm{C}=\mathrm{O}$ addition. The calculations also show that the acyclic double-addition product 11a is $30.5 \mathrm{~kJ} \mathrm{~mol}^{-1}$ more stable than its precursor 10a whereas the alternative acyclic double-addition adduct $\mathbf{1 1 b}$ is, curiously, found to be unstable at this level of calculation. In

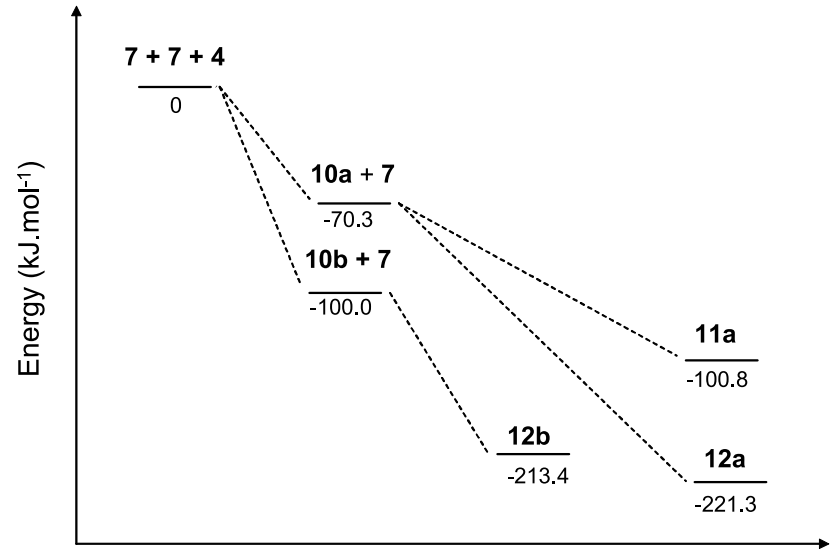

Figure 3. Energy diagram calculated at Becke3LYP//6-311 + $G(d, p)$ level for consecutive additions of ethyl isocyanate (7) to the singly charged acylium-thioacylium ion 4 , that is, $[\mathrm{O}=\mathrm{C}=\mathrm{N}=\mathrm{C}=\mathrm{S}]^{+}$. Energies are given in $\mathrm{kJ} \mathrm{mol}^{-1}$. The acyclic double-addition product is found to be unstable at this level of calculation. See Scheme 5 for the corresponding structures.

addition, the cyclic double-addition products $12 \mathrm{a}$ and $\mathbf{1 2 b}$ are predicted to be by far the most stable products, formed via very exothermic reactions: -221.3 and $-213.4 \mathrm{~kJ} \mathrm{~mol}^{-1}$, respectively. Furthermore, the small difference in energy for these double-addition cyclic products, of just $7.9 \mathrm{~kJ} \mathrm{~mol}^{-1}$, indicates that both 12a and $\mathbf{1 2 b}$ are concomitantly formed in the gas phase.

\section{Conclusions}

Acylium and thioacylium ions were reacted with ethyl isocyanate and ethyl isothiocyanate in the gas-phase. Owing likely to its lower proton affinity that disfavors proton transfer reactions, double addition products are formed to great extents in reactions with the neutral ethyl isocyanate. In reactions with the neutral ethyl isothiocyanate, either the mono-adduct or proton transfer products, or both, dominate. CID experiments reveal that the mono- and double-addition products dissociate

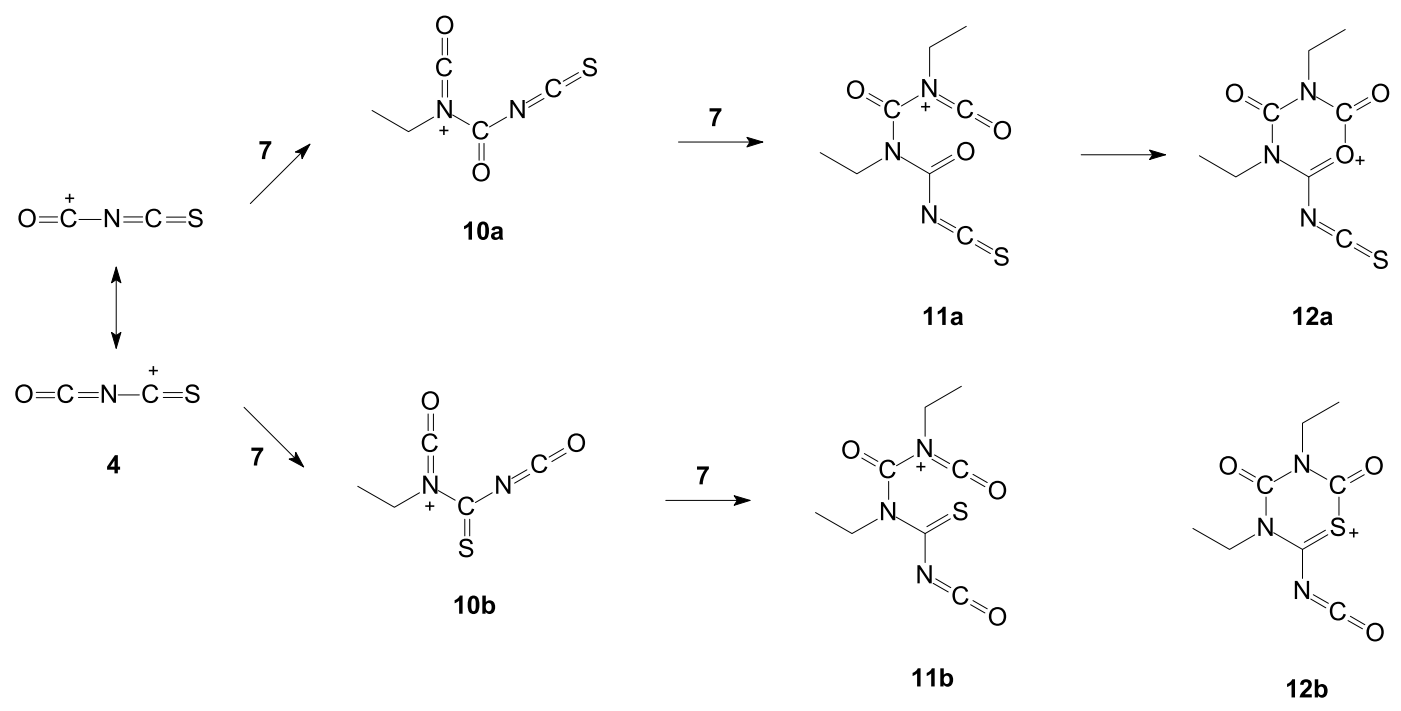

Scheme 5 
exclusively by retro-addition. Ab initio calculations at the Becke3LYP//6-311 + G(d,p) level indicate that, similarly to what is observed in solution, cyclization is greatly favored for the double-addition products in the gas-phase, and that 3,4-dihydro-2,4-dioxo-2H-1,3,5oxadiazinium ions are formed.

\section{Acknowledgments}

The authors thank the Research Support Foundation of the State of Sao Paulo (FAPESP) and the Brazilian National Research Council (CNPq) for financial support.

\section{References}

1. McLafferty, F. W. Tandem Mass Spectrometry-from Infancy to Maturity in 25 Years. Org. Mass Spectrom. 1993, 28, 14031406.

2. Futrell, J. H. Development of Tandem Mass Spectrometry: One Perspective. Int. J. Mass Spectrom. 2000, 200, 495-508.

3. Shukla, A. K.; Futrell, J. H. Tandem Mass Spectrometry: Dissociation of Ions by Collisional Activation. J. Mass Spectrom. 2000, 35, 1069-1090.

4. Stirk, K. M.; Kiminkinen, L. K. M.; Kenttamaa, H. I. Ion Molecule Reactions of Distonic Radical Cations. Chem. Rev. 1992, 92, 1649-1665.

5. Brodbelt, J. S. Analytical Applications of Ion-Molecule Reactions. Mass Spectrom. Rev. 1997, 16, 91-110.

6. Green, M. K.; Lebrilla, C. B. Ion-Molecule Reactions as Probes of Gas-Phase Structures of Peptides and Proteins. Mass Spectrom. Rev. 1997, 16, 53-71.

7. Eberlin, M. N. Triple-Stage Pentaquadrupole (QqQqQ) Mass Spectrometry and Ion-Molecule Reactions. Mass Spectrom. Rev. 1997, 16, 113-144.

8. Takashima, K.; Riveros, J. M. Gas-Phase Solvated Negative Ions. Mass Spectrom. Rev. 1998, 17, 409-430.

9. Filippi, A.; Giardini, A.; Piccirillo, S.; Speranza, M. Gas-Phase Enantioselectivity. Int. J. Mass Spectrom. 2000, 198, 137-163.

10. Eberlin, M. N. Gas-Phase Polar Cycloadditions. Int. J. Mass Spectrom. 2004, 235, 263-278.

11. Ramirez-Arizmendi, L. E.; Yu, Y. Q.; Kenttamaa, H. I. Reactivity of $\mathrm{Cl}-\mathrm{P}^{+}-\mathrm{Cl}$ Toward Cyclic Organic Ethers. J. Am. Soc. Mass Spectrom. 1999, 10, 379-385.

12. Wang, F.; Tao, W. A.; Gozzo, F. C.; Eberlin, M. N.; Cooks, R. G. Synthesis of B- and P-Heterocycles by Reaction of Cyclic Acetals and Ketals with Borinium and Phosphonium Ions. J. Org. Chem. 1999, 64, 3213-3223.

13. Kretzschmar, I.; Schroder, D.; Schwarz, H.; Rue, C.; Armentrout, P. B. Thermochemistry and Reactivity of Cationic Scandium and Titanium Sulfide in the Gas Phase. J. Phys. Chem. A 2000, 104, 5046-5058.

14. O'Hair, R. A. J.; Androutsopoulos, N. K. Can Transacylation Reactions Occur via $\mathrm{S}(\mathrm{N}) 2$ Pathways in the Gas Phase? Insights via Ion-Molecule Reactions of N-Acylpyridinium Ions and ab Initio Calculations. Org. Lett. 2000, 2, 2567-2570.

15. Gevrey, S.; Luna, A.; Taphanel, M. H.; Tortajada, J.; Morizur, J. P. Experimental and Theoretical Studies of the Gas-Phase Reactivity of the $(\mathrm{HO})_{2} \mathrm{P}=\mathrm{O}^{+}$Phosphonium Ions Towards Methanol. Int. J. Mass Spectrom. 2000, 196, 545-563.

16. de Moraes, P. R. P.; Linnert, H. V.; Aschi, M.; Riveros, J. M. Experimental and Theoretical Characterization of Long-Lived Triplet State $\mathrm{CH}_{3} \mathrm{CH}_{2} \mathrm{~S}^{+}$Cations. J. Am. Chem. Soc. 2000, 122, 10133-10142.

17. D'Oca, M. G. M.; Moraes, L. A. B.; Pilli, R. A.; Eberlin, M. N. Intrinsic Gas-Phase Electrophilic Reactivity of Cyclic N-Alkyl and N-Acyliminium Ions. J. Org. Chem. 2001, 66, 3854-3864.
18. Tomazela, D. M.; Moraes, L. A. B.; Pilli, R. A.; Eberlin, M. N.; D'Oca, M. G. M. Mannich-Type Reactions in the Gas-Phase: The Addition of Enol Silanes to Cyclic N-Acyliminium Ions. J. Org. Chem. 2002, 67, 4652-4658.

19. Gronert, S. Mass Spectrometric Studies of Organic IonMolecule Reactions. Chem. Rev. 2001, 101, 329-360.

20. Sparrapan, R.; Mendes, M. A.; Carvalho, M.; Eberlin, M. N. Formal Fusion of a Pyrrole Ring onto 2-Pyridyl and 2-Pyrimidyl Cations: One-Step Gas-Phase Synthesis of Indolizine and Its Derivatives. Chem. Eur. J. 2000, 6, 321-326.

21. Augusti, R.; Gozzo, F. C.; Moraes, L. A. B.; Sparrapan, R.; Eberlin, M. N. The Simplest Azabutadienes in their N-Protonated Forms. Generation, Stability, and Cycloaddition-Reactivity in the Gas Phase. J. Org. Chem. 1998, 63, 4889-4897.

22. Moraes, L. A. B.; Eberlin, M. N.; Laali, K. K. Gas-Phase Synthesis and Characterization of an Azaphosphirenium Ion: The First N,P-Analog of the Aromatic Cyclopropenyl Cation. Organometallics 2001, 20, 4863-4868.

23. Takats, Z.; Wiseman, J. M.; Gologan, B.; Cooks, R. G. Mass Spectrometry Sampling Under Ambient Conditions with Desorption Electrospray Ionization. Science 2004, 306, 471-473.

24. Eberlin, M. N.; Cooks, R. G. Polar $\left[4+2^{+}\right]$Diels-Alder Cycloadditions of Acylium Ions in the Gas-Phase. J. Am. Chem. Soc. 1993, 115, 9226-9233.

25. Moraes, L. A. B.; Eberlin, M. N. Ketalization of Gaseous Acylium Ions. J. Am. Soc. Mass Spectrom. 2001, 12, 150-162.

26. Moraes, L. A. B.; Eberlin, M. N. The Gas-Phase Meerwein Reaction. Chem. Eur. J. 2000, 6, 897-905.

27. Moraes, L. A. B.; Eberlin, M. N. Structurally Diagnostic IonMolecule Reactions: Acylium Ions with $\alpha-, \beta-$, and $\gamma$-Hydroxy Ketones. J. Mass Spectrom. 2002, 37, 162-168.

28. Lemos, A. B.; Sparrapan, R.; Eberlin, M. N. Reactions of Gaseous Acylium Ions with 1,3-Dienes: Further Evidence for Polar $[4+2(+)]$ Diels-Alder Cycloaddition. J. Mass Spectrom. 2003, 38, 305-314.

29. Meurer, E. C.; Eberlin, M. N. Mono and Double Polar [4+ $2^{+}$] Diels-Alder Cycloaddition of Acylium Ions with OHeterodienes. J. Mass Spectrom. 2002, 37, 146-154.

30. Meurer, E. C.; Moraes, L. A. B.; Eberlin, M. N. Cyclization of Acylium Ions with Nitriles: Gas-Phase Synthesis and Characterization of 1,3,5-Oxadiazinium Ions. Int. J. Mass Spectrom. 2001, 212, 445-454.

31. Mahato, S. B. Advances in the Chemistry of Friedel - Crafts Acylation. J. Indian Chem. Soc. 2000, 77, 175-191.

32. Altalib, M.; Tashtoush, H. Recent Advances in the Use of Acylium Salts in Organic Synthesis-A Brief Review. Org. Prep. Proced. Int. 1990, 22, 1.

33. Hamed, A.; Ismail, A.; Hitzler, M. G.; Jochims, J. C. On the Reaction of Acylium Salts with Isocyanates. J. Prakt. Chem./ Chem. Ztg. 1995, 337, 385-390.

34. Juliano, V. F.; Gozzo, F. C.; Eberlin, M. N.; Kascheres, C.; doLago, C. L. Fast Multidimensional (3D and 4D) $\mathrm{MS}^{2}$ and $\mathrm{MS}^{3}$ Scans in a High-Transmission Pentaquadrupole Mass Spectrometer. Anal. Chem. 1996, 68, 1328-1334.

35. Tiernan, T. O.; Futrell, J. H. Ionic Reactions in Unsaturated Compounds. Ethylene. J. Phys. Chem. 1968, 72, 3080-3081.

36. Schwartz, J. C.; Wade, A. P.; Enke, C. G.; Cooks, R. G. Systematic Delineation of Scan Modes in Multidimensional Mass Spectrometry. Anal. Chem. 1990, 62, 1809-1818.

37. Becke, A. D. Density-Functional Thermochemistry. The Role of Exact Exchange. J. Chem. Phys. 1993, 98, 5648-5652.

38. Lee, C.; Parr, R. G. Exchange-Correlation Functional for Atoms and Molecules. Phys. Rev. A 1990, 42, 193-200.

39. Stephens, P. J.; Devlin, F. J.; Chabalowski, C. F.; Frisch, M. J. Ab-Initio Calculation of Vibrational Absorption and CircularDichroism Spectra Using Density-Functional Force Fields. J. Phys. Chem. 1994, 98, 11623-11627. 
40. Frisch, M. J.; Trucks, G. W.; Schlegel, H. B.; Scuseria, G. E.; Robb, M. A.; Cheeseman, J. R.; Zakrzewski, V. G.; Montgomery Jr., J. A. Montgomery, J.; Stratmann, R. E.; Burant, J. C.; Dapprich, S.; Millam, J. M.; Daniels, D.; Kudin, K. N.; Strain, M. C.; Farkas, O.; Tomasi, J.; Barone, V.; Cossi, M.; Cammi, R.; Mennucci, B.; Pomelli, C.; Adamo, C.; Clifford, S.; Ochterski, J.; Petersson, G. A.; Ayala, P. Y.; Cui, Q.; Morokuma, K.; Malick, D. K.; Rabuck, D.; Raghavachari, K.; Foresman, J. B.; Cioslowski, J.; Ortiz, J. V.; Stefanov, B.; Liu, G.; Liashenko,
A.; Piskorz, P.; Komaromi, I.; Gomperts, R.; Martin, R. L.; Fox, J.; Keith, T.; Al-Laham, M. A.; Peng, Y.; Nanayakkara, A.; Gonzalez, C.; Challacombe, M.; Gill, P. M. W.; Johnson, B.; Chen, W.; Wong, M. W.; Andres, J. L.; Head-Gordon, M.; Replogle, E. S.; Pople, J. A. Gaussian 98; Gaussian, Inc.: Pittsburgh PA, Revision A6.

41. Hunter, E. P.; Lias, S. G. Evaluated Gas Phase Basicities and Proton Affinities of Molecules: An Update. J. Phys. Chem. Ref. Data 1998, 27, 413-656. 